\title{
Morphological Character and Seed Yield Potential of Coriander Genotypes under Gangetic Alluvial Region of West Bengal
}

\author{
Akoijam Ranjita Devi* and A.B. Sharangi
}

Department of Spices and Plantation Crops, Faculty of Horticulture, Bidhan Chandra Krishi Viswavidyalaya, Mohanpur-741252, Nadia, West Bengal, India

*Corresponding author

\begin{tabular}{|c|c|}
\hline & A B S T R A C T \\
\hline $\begin{array}{l}\text { Ke y w o r d s } \\
\text { Coriander } \\
\text { Genotypes, } \\
\text { Coriandrum } \\
\text { sativum }\end{array}$ & \multirow{3}{*}{$\begin{array}{l}\text { The present investigation was carried out during the year 2014-15 and 2015-16 for } \\
\text { studying the yield and quality parameters in } 12 \text { germplasms at HRS, Mandouri, Bidhan } \\
\text { Chandra Krishi Viswavidyalaya, Nadia, West Bengal. The experimental design was RBD } \\
\text { and evaluation studies were carried out on the basis of morphology and yield parameters. } \\
\text { The germplasm NRCS A.Cr-1 showed the maximum days to flower.Days to harvest were } \\
\text { minimum ingenotype Manipur collection-1. Plant height, length oflongest basal leaves, } \\
\text { Number of umbels per plant, number of umbellets per umbel, test weight, seed yield per } \\
\text { plant, yield per plot, and projected yield per hectare were recorded maximum in the vareity } \\
\text { Pant Haritma. Number of basal leaves was recorded highest in Arka Isha with } 9.50 \text { per } \\
\text { plant. Number of primary branches, number of secondary branches and number of seed per } \\
\text { umbel were highest in NRCSS A.Cr-1 }\end{array}$} \\
\hline Article Info & \\
\hline $\begin{array}{l}\text { Accepted: } \\
\text { 07 March } 2019 \\
\text { Available Online: } \\
10 \text { April } 2019\end{array}$ & \\
\hline
\end{tabular}

\section{Introduction}

Spices are low volume high value crops which play vital role in our national economy and international market. The association of spices and mankind is prehistoric. They are used as flavouring, food additives, colouring agents, body toners, preservatives, contraceptives, cosmetics and in various ailments. India has been the leading spice producing and exporting country of the world since the recorded history. It constitutes an important group of agricultural commodities, since antiquity and has been considered virtually indispensable in culinary art.
Coriander (Coriandrum sativum L.) is an important annual spice herb that belongs to the family Umbelliferae/Apiaceae (Hedburg and Hedburg, 2003). It is a diploid cross pollinated crop. The plant, indigenous to Southern Europe and the Mediterranean region, is one of oldest consumed spices in India. The green unripened fruits have unpleasant fetid bug like odour. However, when ripe, the seeds have a distinctive sweet citrus/mint/musty aroma that has been valued over the centuries.

It is commercially grown in India, Egypt, Morocco, USSR, USA, Hungary, Poland, Rumania, Mexico, Czechoslovakia and 
Guatemala. Coriander is exported to other countries like Malaysia, Singapore, Australia and Central European countries. By exporting 35,185 tonnes, it fetched Rs /-272, 74 crore (Spice Board, 2019). India has prime position in cultivation and production of coriander. The production in India during the year 2013 14 is $496240 \mathrm{t}$ (Spice Board, 2019). The main coriander growing states in India are Andhra Pradesh, Rajasthan, Madhya Pradesh, Karnataka, Tamil Nadu and Uttar Pradesh. Rajasthan emerges as the largest producer with $63 \%$ of domestic production. In 19931994 India exported $13552 \mathrm{t}$ of coriander seeds and imported $73 \mathrm{t}$ of coriander seed oil. Like other spices, the productivity of coriander is $1011 \mathrm{~kg}$ per hectare.

The essential oil coriander has antibacterial property. In India, the decoctions of coriander seeds along with cumin are traditionally used as diuretic. It is pharmacologically proven to have chemopreventive (Lakhera et al., 2015), antidiabetic (Mazhar and Mazumder, 2013), anti-inflamatory (Mohan et al., 2013) and anti-diarrheal (Nithya, 2015) the seeds form a main component in the preparation of curry powder and in preparation of various pickles. They are used for flavouring pastry, cookiescakes, tobacco, bakery product, meat fish, soda, syrups, candy, preserve and liquor (Thamburaj and Singh, 2004). It is used as a spice in culinary (Diederichsen, 1996), medicine (Kubo et al., 2004; Delaquis et al., 2002). The main flavour compound are dlinalool, $\alpha, \beta$-pinene and p-cymene. The seed contains significant quantities of vitamins (Holland et al., 1991); minerals and dietary fiber (Ensminger and Esminger, 1986).

The average seed yield of coriander is rather low in spite of its wide cultivation in India, because of lack of attention given to this crop. In order to exploit the yield potential of coriander, the factors affecting yield and yield component should be thoroughly investigated.
These factors include environment and cultural practices which directly affect the yield. The productivity of coriander has increased substantially due to rapid development of varieties. However, fewer attempts have been made to standardize them for various locations. Since several germplasms are available for cultivation, it is necessary to identify the potential genotype for the prevailing agro-climatic conditions.

Coriander is grown in almost all the districts of West Bengal. Mostly local cultivars/landraces are predominant in the state. Characterization of local and promising genetic resources for identification of important traits for further utilization is important in the present day breeding programme.

\section{Materials and Methods}

The present investigation was carried out at Horticultural Research Station, Mandouri, Faculty of Horticulture, Bidhan Chandra Krishi Viswavidyalaya, Nadia, West Bengal during the year 2014-15 and 2015-16. The research station is located at $23.5^{\circ}$ North latitude, $89^{\circ}$ East longitude having an average altitude of $9.75 \mathrm{~m}$ above mean sea level.

The design of the experiment was randomized block design (RBD) with 12 number of treatments, 3 replications. The plot size was $1.8 \mathrm{~m} \times 1 \mathrm{~m}$ and the spacing adopted was $25 \mathrm{~cm} \times 15 \mathrm{~cm}$. There were 48 numbers of plants per plot. Time of planting was $10^{\text {th }} \mathrm{Nov}$ 2014 and $10^{\text {th }}$ Nov, 2015 (Table 1).

One deep ploughing with tractor followed by two ploughings with power tiller was done in order to make soil friable and pulverized. Levelling was done properly as far as practicable with the help of ladder to avoid water stagnation. Well rotten Farm Yard Manure (FYM) @ 20t/ha and N, P and K 
were applied at the rate of 30:40:20 kg. Half dose of $\mathrm{N}$ and full dose of $\mathrm{P}$ and $\mathrm{K}$ were applied as basal and remaining half dose of $\mathrm{N}$ was applied 30 days after sowing. The sources of $\mathrm{N}, \mathrm{P}_{2} \mathrm{O}_{5}$ and $\mathrm{K}_{2} \mathrm{O}$ were Urea, single super phosphate and muriate of potash respectively. Seed of coriander were soaked overnight for better and quick germination and dried under shade and were. The seeds were sown in line with spacing of $25 \mathrm{~cm}$ (row to row) $\times 15 \mathrm{~cm}$ (plant to plant). Thinning and hoeing was done 30 days after sowing along with first weeding. Irrigation was given once in a week after sowing to enhance uniform seed germination. The crop was harvested when 60 per cent of seeds in main umbels turn yellowish brown in colour.

\section{Results and Discussion}

Days to flowering differs significantly in all the genotypes ranging from 44.83-77.17days (Table 2). The germplasm NRCS A.Cr-1 showed the maximum days followed by Five X, Pant Haritma. West Bengal collection 1 was found to take minimum days to flowering. Phurailatpam et al., (2016) stated that days to flowering ranges from 42.67-
68.67. In case of days to harvesting the germplasm Manipur collection-1 was the earliest to harvest (94.17 days) followed by Assam collection whereas NRCS A.Cr1 took maximum days (130.33) to harvest. Arif et al., (2014) recorded 176-200 days to harvesting and Singh et al., (2011) recorded 139.33-142.33 days. Pant Haritma was found tallest $(114.98 \mathrm{~cm})$ whereas Tripura collection was the shortest $(64.76 \mathrm{~cm})$. The result of Moniruzzaman et al., (2013) showed the plant height ranging from 60.40-100.40 cm. Number of basal leaves was found highest in Arka Isha (9.50) followed by Pant Haritma. West Bengal collection1 showed the least number of basal leaves. The results are in line with Arif et al., (2014), ranging from 3 - 23.2. Length of longest basal leaves was found maximum Pant Haritma (19.90) followed by Suvashini (14.40), West Bengal Collection-3. While West Bengal collection-1 showed the minimum. The highest number of primary branch was found in NRCS A. Cr1 (10.50) whereas Manipur collection-2 was recorded the least (3.83).Similar result were observed by Meena et al., (2014) and Bhandhari and Gupta (1993).

Table.1 Collection of different genotypes of coriander

\begin{tabular}{|c|l|l|}
\hline Treatments & Germplasms & \multicolumn{1}{|c|}{ Collected from } \\
\hline $\mathbf{1 .}$ & Arka Isha & IIHR, Bangalore \\
\hline $\mathbf{2 .}$ & Manipur collection-1 & Imphal, Manipur \\
\hline $\mathbf{3 .}$ & Suvashini & Gayespur, West Bengal \\
\hline $\mathbf{4 .}$ & West Bengal collection-1 & Mohanpur, West Bengal \\
\hline $\mathbf{5 .}$ & West Bengal collection-2 & Mohanpur, West Bengal \\
\hline $\mathbf{6 .}$ & Assam collection & Jorhat, Assam \\
\hline $\mathbf{7 .}$ & Five - X & Gayespur, West Bengal \\
\hline $\mathbf{8 .}$ & Manipur collection-2 & Imphal, Manipur \\
\hline $\mathbf{9 .}$ & NRCS A.Cr-1 & NRCS, Ajmer \\
\hline $\mathbf{1 0 .}$ & Tripura collection & Tripura \\
\hline $\mathbf{1 1}$ & Pant Haritma & GBPUAT, Pantnagar \\
\hline $\mathbf{1 2}$ & West Bengal collection-3 & Cooch Behar, West \\
\hline & & Bengal \\
\hline
\end{tabular}


Table.2 Performance of coriander genotypes in two years for growth

\begin{tabular}{|c|c|c|c|c|c|c|c|c|c|c|c|c|c|c|c|c|c|c|}
\hline \multirow[t]{2}{*}{ Genotypes } & \multicolumn{3}{|c|}{ Days to flowering } & \multicolumn{3}{|c|}{ Days to maturity } & \multicolumn{3}{|c|}{ Plant height(cm) } & \multicolumn{3}{|c|}{ No. basal leaves } & \multicolumn{3}{|c|}{$\begin{array}{l}\text { Length of longest } \\
\text { basal leaves }\end{array}$} & \multicolumn{3}{|c|}{ No.Primary branches } \\
\hline & $\begin{array}{l}1^{\text {st }} \\
\text { year }\end{array}$ & $\begin{array}{l}\text { 2nd } \\
\text { year }\end{array}$ & Pool & $\begin{array}{l}1^{\text {st }} \\
\text { year }\end{array}$ & $\begin{array}{l}\text { 2nd } \\
\text { year }\end{array}$ & Pool & $\begin{array}{l}1^{\text {st }} \\
\text { year }\end{array}$ & $\begin{array}{l}\text { 2nd } \\
\text { year }\end{array}$ & Pool & $\begin{array}{l}1^{\text {st }} \\
\text { year }\end{array}$ & $\begin{array}{l}\text { 2nd } \\
\text { year }\end{array}$ & Pool & $\begin{array}{l}1^{\text {st }} \\
\text { year }\end{array}$ & $\begin{array}{l}\text { 2nd } \\
\text { year }\end{array}$ & Pool & $\begin{array}{l}1^{\text {st }} \\
\text { year }\end{array}$ & $\begin{array}{l}\text { 2nd } \\
\text { year }\end{array}$ & Pool \\
\hline Arka Isha & 67.67 & 70.67 & 69.17 & 105.67 & 106.67 & 106.17 & 115.33 & 114.52 & 114.93 & 9.33 & 9.67 & 9.50 & 12.90 & 13.23 & 13.07 & 5.67 & 5.33 & 5.50 \\
\hline Manipur collection-1 & 50.00 & 51.33 & 50.67 & 93.67 & 94.67 & 94.17 & 74.67 & 69.89 & 72.28 & 3.67 & 3.33 & 3.50 & 12.73 & 12.83 & 12.78 & 5.33 & 5.67 & 5.50 \\
\hline Suvashini & 59.33 & 58.33 & 58.83 & 102.33 & 103.67 & 103.00 & 106.02 & 106.41 & 106.21 & 5.67 & 6.67 & 6.17 & 14.30 & 14.50 & 14.40 & 6.67 & 6.33 & 6.50 \\
\hline $\begin{array}{l}\text { West Bengal } \\
\text { collection-1 }\end{array}$ & 43.33 & 46.33 & 44.83 & 99.00 & 100.67 & 99.83 & 76.83 & 75.85 & 76.34 & 3.33 & 3.00 & 3.17 & 9.30 & 9.27 & 9.28 & 4.33 & 4.67 & 4.50 \\
\hline $\begin{array}{l}\text { West Bengal } \\
\text { collection-2 }\end{array}$ & 53.00 & 57.67 & 55.33 & 119.00 & 118.67 & 118.83 & 108.11 & 102.91 & 105.51 & 7.67 & 7.33 & 7.50 & 11.97 & 12.30 & 12.13 & 7.33 & 7.00 & 7.17 \\
\hline Assam collection & 42.33 & 47.33 & 44.83 & 96.67 & 98.67 & 97.67 & 78.33 & 76.26 & 77.30 & 4.33 & 3.67 & 4.00 & 12.50 & 12.10 & 12.30 & 4.00 & 4.33 & 4.17 \\
\hline Five $-X$ & 73.33 & 71.00 & 72.17 & 117.33 & 118.00 & 117.67 & 108.67 & 102.86 & 105.76 & 6.67 & 6.33 & 6.50 & 9.60 & 9.73 & 9.67 & 7.33 & 7.67 & 7.50 \\
\hline Manipur collection-2 & 57.67 & 57.33 & 57.50 & 109.67 & 110.67 & 110.17 & 70.95 & 72.99 & 71.97 & 3.33 & 3.67 & 3.50 & 12.33 & 12.17 & 12.25 & 4.00 & 3.67 & 3.83 \\
\hline NRCSS A.Cr-1 & 77.00 & 77.33 & 77.17 & 129.33 & 131.33 & 130.33 & 113.28 & 111.71 & 112.49 & 6.33 & 6.33 & 6.33 & 12.90 & 12.83 & 12.87 & 10.33 & 10.67 & 10.50 \\
\hline Tripura collection & 48.67 & 50.00 & 49.33 & 100.33 & 98.00 & 99.17 & 64.33 & 65.19 & 64.76 & 4.33 & 4.67 & 4.50 & 11.00 & 10.53 & 10.77 & 4.67 & 5.00 & 4.83 \\
\hline Pant Haritma & 70.33 & 70.33 & 70.33 & 125.00 & 125.67 & 125.33 & 111.55 & 118.41 & 114.98 & 8.67 & 8.00 & 8.33 & 20.03 & 19.77 & 19.90 & 9.67 & 10.00 & 9.83 \\
\hline $\begin{array}{l}\text { West Bengal } \\
\text { collection-3 }\end{array}$ & 64.67 & 65.33 & 65.00 & 107.67 & 108.67 & 108.17 & 83.67 & 83.00 & 83.33 & 6.33 & 6.67 & 6.50 & 13.70 & 13.93 & 13.82 & 3.67 & 4.33 & 4.00 \\
\hline SE(m) & 1.84 & 1.59 & 1.27 & 0.74 & 0.97 & 0.61 & 3.84 & 3.34 & 3.37 & 0.33 & 0.42 & 0.30 & 0.34 & 0.45 & 0.34 & 0.36 & 0.37 & 0.30 \\
\hline CD at $5 \%$ & 5.38 & 4.66 & 3.73 & 2.16 & 2.85 & 1.80 & 11.25 & 9.79 & 9.88 & 0.97 & 1.23 & 0.87 & 0.98 & 1.33 & 0.99 & 1.05 & 1.08 & 0.87 \\
\hline
\end{tabular}


Table.3 Growth and seed character of coriander genotypes under Gangetic alluvial soils

\begin{tabular}{|c|c|c|c|c|c|c|c|c|c|c|c|c|c|c|c|}
\hline \multirow[t]{2}{*}{ Genotypes } & \multicolumn{3}{|c|}{ No. Secondary branches } & \multicolumn{3}{|c|}{ No. umbels/plant } & \multicolumn{3}{|c|}{ No. umbellets/umbel } & \multicolumn{3}{|c|}{ No. seeds/umbel } & \multicolumn{3}{|c|}{ Test Weight } \\
\hline & $\mathbf{1}^{\text {st }}$ year & $\begin{array}{l}\text { 2nd } \\
\text { year }\end{array}$ & Pool & $\begin{array}{l}1^{\text {st }} \\
\text { year }\end{array}$ & $\begin{array}{l}\text { 2nd } \\
\text { year }\end{array}$ & Pool & $\mathbf{1}^{\text {st }}$ year & 2nd year & Pool & $1^{\text {st }}$ year & $\begin{array}{l}\text { 2nd } \\
\text { year }\end{array}$ & Pool & $1^{\text {st }}$ year & 2nd year & Pool \\
\hline Arka Isha & 12.33 & 12.00 & 12.17 & 22.31 & 22.28 & 22.30 & 4.25 & 4.24 & 4.25 & 36.76 & 36.31 & 36.54 & 8.20 & 8.07 & 8.13 \\
\hline Manipur collection-1 & 11.00 & 12.33 & 11.67 & 21.14 & 21.24 & 21.19 & 4.00 & 4.03 & 4.02 & 22.22 & 21.67 & 21.94 & 7.32 & 7.40 & 7.36 \\
\hline Suvashini & 11.67 & 12.67 & 12.17 & 23.33 & 23.00 & 23.17 & 5.59 & 5.48 & 5.53 & 34.33 & 35.24 & 34.78 & 7.72 & 7.80 & 7.76 \\
\hline West Bengal collection-1 & 8.00 & 9.67 & 8.83 & 17.61 & 17.34 & 17.48 & 3.88 & 3.82 & 3.85 & 30.55 & 31.20 & 30.88 & 6.94 & 6.80 & 6.87 \\
\hline West Bengal collection-2 & 12.67 & 13.33 & 13.00 & 27.77 & 27.67 & 27.72 & 5.69 & 5.43 & 5.56 & 46.22 & 45.99 & 46.11 & 7.58 & 7.70 & 7.64 \\
\hline Assam collection & 7.67 & 8.33 & 8.00 & 19.78 & 19.63 & 19.70 & 4.38 & 4.18 & 4.28 & 29.14 & 30.68 & 29.91 & 7.34 & 7.41 & 7.37 \\
\hline Five- $\mathbf{X}$ & 15.00 & 15.33 & 15.17 & 26.00 & 26.00 & 26.00 & 4.90 & 4.64 & 4.77 & 40.03 & 39.95 & 39.99 & 7.14 & 7.14 & 7.14 \\
\hline Manipur collection-2 & 8.33 & 7.67 & 8.00 & 16.66 & 16.17 & 16.42 & 4.39 & 4.33 & 4.36 & 32.75 & 31.84 & 32.30 & 6.82 & 6.90 & 6.86 \\
\hline NRCSS A.Cr-1 & 17.00 & 18.00 & 17.50 & 24.02 & 24.23 & 24.12 & 6.08 & 6.16 & 6.12 & 51.83 & 50.77 & 51.30 & 6.94 & 7.20 & 7.07 \\
\hline Tripura collection & 10.00 & 10.00 & 10.00 & 20.30 & 20.11 & 20.21 & 3.64 & 3.86 & 3.75 & 29.94 & 29.88 & 29.91 & 7.66 & 7.78 & 7.72 \\
\hline Pant Haritma & 15.67 & 16.00 & 15.83 & 29.81 & 29.98 & 29.89 & 6.91 & 7.13 & 7.02 & 45.05 & 45.38 & 45.21 & 9.98 & 9.49 & 9.74 \\
\hline West Bengal collection-3 & 12.33 & 12.00 & 12.17 & 20.59 & 19.76 & 20.18 & 5.79 & 5.87 & 5.83 & 23.75 & 24.23 & 23.99 & 9.30 & 9.41 & 9.36 \\
\hline SE(m) & 0.64 & 0.96 & 0.60 & 0.87 & 0.85 & 0.67 & 0.19 & 0.19 & 0.17 & 1.31 & 1.29 & 0.93 & 0.14 & 0.11 & 0.12 \\
\hline CD at $5 \%$ & 1.89 & 2.82 & 1.76 & 2.57 & 2.49 & 1.96 & 0.56 & 0.56 & 0.50 & 3.84 & 3.78 & 2.72 & 0.42 & 0.32 & 0.35 \\
\hline
\end{tabular}


Table.4 Yield and yield contributing character of coriander under Gangetic alluvial soils

\begin{tabular}{|c|c|c|c|c|c|c|c|c|c|}
\hline \multirow[t]{2}{*}{ Genotypes } & \multicolumn{3}{|c|}{ Seed yield/plant(g) } & \multicolumn{3}{|c|}{ Yield/plot(g) } & \multicolumn{3}{|c|}{ Projected yield/ha(q) } \\
\hline & $\begin{array}{l}1^{\text {st }} \\
\text { year }\end{array}$ & $\begin{array}{l}\text { 2nd } \\
\text { year }\end{array}$ & Pool & $1^{\text {st }}$ year & $\begin{array}{l}\text { 2nd } \\
\text { year }\end{array}$ & Pool & $\begin{array}{l}1^{\text {st }} \\
\text { year }\end{array}$ & $\begin{array}{l}\text { 2nd } \\
\text { year }\end{array}$ & Pool \\
\hline Arka Isha & 2.44 & 2.72 & 2.58 & 300.75 & 303.25 & 302.00 & 15.04 & 15.16 & 15.10 \\
\hline Manipur collection-1 & 1.21 & 1.27 & 1.24 & 150.70 & 159.37 & 155.04 & 7.54 & 7.97 & 7.75 \\
\hline Suvashini & 2.66 & 2.51 & 2.59 & 292.44 & 282.36 & 287.40 & 14.62 & 14.12 & 14.37 \\
\hline $\begin{array}{l}\text { West Bengal collection- } \\
1\end{array}$ & 3.29 & 3.25 & 3.27 & 278.09 & 266.99 & 272.54 & 13.90 & 13.35 & 13.63 \\
\hline $\begin{array}{l}\text { West Bengal collection- } \\
2\end{array}$ & 5.73 & 5.76 & 5.75 & 336.33 & 343.16 & 339.75 & 16.82 & 17.16 & 16.99 \\
\hline Assam collection & 1.63 & 1.87 & 1.75 & 172.81 & 180.14 & 176.48 & 8.64 & 9.01 & 8.82 \\
\hline Five- $\mathrm{X}$ & 3.78 & 3.66 & 3.72 & 327.08 & 320.82 & 323.95 & 16.35 & 16.04 & 16.20 \\
\hline Manipur collection-2 & 1.12 & 1.18 & 1.15 & 181.13 & 190.79 & 185.96 & 9.06 & 9.54 & 9.30 \\
\hline NRCSS A.Cr-1 & 5.52 & 5.67 & 5.60 & 382.67 & 386.00 & 384.33 & 19.13 & 19.30 & 19.22 \\
\hline Tripura collection & 3.50 & 3.38 & 3.44 & 218.92 & 235.26 & 227.09 & 10.95 & 11.76 & 11.35 \\
\hline Pant Haritma & 6.03 & 6.31 & 6.17 & 442.04 & 448.71 & 445.37 & 22.10 & 22.44 & 22.27 \\
\hline $\begin{array}{l}\text { West Bengal collection- } \\
3\end{array}$ & 2.14 & 2.18 & 2.16 & 295.58 & 294.87 & 295.23 & 14.78 & 14.74 & 14.76 \\
\hline SE(m) & 0.16 & 0.14 & 0.13 & 3.66 & 5.42 & 3.88 & 0.18 & 0.27 & 0.19 \\
\hline CD at $5 \%$ & 0.48 & 0.42 & 0.37 & 10.73 & 15.90 & 11.39 & 0.54 & 0.79 & 0.57 \\
\hline
\end{tabular}

In case of secondary branch NRCS A.Cr-1 was recorded the highest number (17.77) followed by Pant Haritma (15.83), Assam collection (8.00) showed the least. According to Datta and Choudhari (2006) number of secondary branches ranges from 10.10-16.75. So far as the umbels per plant in concerned the germplasm Pant Haritma produced the maximum number of umbels per plant (29.89) followed by West Bengal collection-2, Five$\mathrm{X}$. Whereas the germplasm Manipur collection-2 produced the minimum (16.42) number of umbels per plant. The range of umbellets per umbel in all the germplasm under study varied from 7.02 in Pant Haritma to 3.75 in Tripura collection (Table 3). The results are in line with Malik and Tehlan (2013). In case of number of seeds per umbel the maximum value was observed in NRCS A.Cr-1 (51.30) followed by west Bengal collection-2, Pant Haritma. On the other hand the minimum seeds/umbel was found with the germplasm Manipur collection-1 (21.94).
Similar results have been obtained by Meena et al., (2010). Test weight in different germplasms ranged from 9.74 in Pant Haritma to 6.86 in Manipur collection-2 (Table 3). The results are in line with Jain et al., (2017).

Seed yield/plant in different coriander germplasms ranged from $6.17 \mathrm{~g}$ in Pant Haritma to $1.15 \mathrm{~g}$ in Manipur collection-2 as shown in table 4 . The results are in line with Kurubetta et al., (2017). Yield per plot was found highest in highest in Pant Haritma (445.37) followed by NRCS A.Cr-1 (384.33) whereas Manipur collection-1(155.04) recorded the least. The result is in agreement with the observations of Moniruzzaman et al., 2013 and Meena et al., 2010. So far as projected yield per ha is concerned highest yield was obtained in Pant Haritma (22.27) whereas Manipur collection-1 recorded the least of (7.75). Similar results have been obtained by Phurailatpam et al., (2016), Singh et al., (2012) and Giridhar et al., (2014). 
Based on growth and seed yield of coriander genotypes, it can be concluded that the genotypes Pant Haritma followed by NRCSS, A.Cr-1and Arka Isha are suitable for Gangetic alluvial region of West Bengal.

\section{References}

Arif, M., Khurshid, H. and Khan, S. A. (2014). Genetic Structure and Green Leaf Performance Evaluation of Geographically Diverse Population of Coriander (Coriandrum Sativum L.). Eur. Acad. Res. 2(3)

Bhandari, M. M., Gupta, A. (1993). Association analysis in coriander. Indian J. Genet. and Plant Breed. 53(1): 66-70

Datta, S. and Choudhuri, P. (2006). Evaluation of coriander germplasm under terai zone of West Bengal. Haryana J. Hortic. Sci. 35(3/4): 348349

Delaquis, P.J., Stanich, K., Girard, B. and Mazza, G. (2002). Antimicrobial activity of individual and mixed fractions of dill, cilantro, coriander and eucalyptus essential oils. Int.J. Food Microbiol. 74:101-109.

Diederichsen, A. (1996 ). Coriander (Coriandrum sativum L.) promoting the conservation and use of underutilized and neglected crops, 3. Institute of Plant Genetics and Crop Plant Research, Gatersleben/ International Plant Genetic Resources Institute, Rome : 1-82.

Ensminger, A.H, and Esminger, M.K.J. (1986). Food for health: A Nutrition Encyclopedia. Clovis, California: Pegus Press, USA.

Giridhar, K., Kumari, S. S., Rajani, A., Sarada, C and Naidu, N (2014). Identification of potential genotypes of coriander (Coriandrum sativum L.) suitable for rainfed vertisols. Appl.
Biol. Res. 16 (2): 00-00

Hedburg, I and Hedburg, O. (2003). Flora of Ethiopia and Eritrea Apiaceae to Dipsacaceae. Hedeger, I. S. Edwards and Sileshi Nemomsa (Eds.), Uppsala, Sweden. 4(1): 352.

Holland, B., Unwin, I. D. and Buss, D. H. (1991). Vegetables, Herbs and Spices. 4th ed. Cambridge, UK: 163.

Jain, A., Pandey, V.P., Singh, V.B., Singh, and Sriom. (2017). Evaluation of Coriander (Coriandrum sativum L.) Genotypes for Growth and Seed Yield Attributes. International Journal of Current Microbiology and Applied Sciences. 6(8): 597-605.

Kubo, I., Fujita, K., Kubo, A., Nithei, K. and Ogura, T.(2004). Antibacterial activity of coriander volatile compounds against Salmonella Choleraesuis. J. Agric. and Food Chem.52 (1): 33293332

Kurubetta, K, D., Venkatesh, J., Mesta, R. K., Tatagar, M, H., and Kareem, M, D. (2017). Performance Evaluation of Coriander Genotypes for Seed Yield in Northern Transitional Zone of Karnataka. Res. J. Chem. Environ. Sci. 5(6): 13-15.

Lakhera, A., Ganeshpurkar, A., Bansal, D., and Dubey, N. (2015). Chemopreventive role of Coriandrum sativum against gentamicin-induced renal histopathological damage in rats. Interdiscip Toxicol 8(2):99-102

Malik, T. P and Tehlan, S. K (2013). Performance of coriander (Coriandrum sativum L.) varieties for growth and seed yield Int. J. Seed Spices. 3(2):89-90

Mazhar, J. and Mazumder, A. (2013) Evaluation of antidiabetic activity of methanolic leaf extract of Coriandrum sativum in alloxan induced diabetic rats. Res J Pharm Biol Chem Sci 4(3):500-507 
Meena, R. S., Kakani, R. K., Choudhary, S., Singh, B and Panwar, A. (2014). Genetic Diversity Analysis in Coriander (Coriandrum sativum L.) Varieties. Indian J. Agric. Sci. 84 (12)

Mohan, P. V. N., Suganthi, V., and Gowri, S. (2013). Evaluation of antiinflammatory activity in ethanolic extract of Coriandrum sativum L. using carrageenan induced paw oedema in albino rats. Der Pharma Chemica 5(2):139-143

Moniruzzaman, M., Rahman, M. M., Hossain, M. M., Karim, A. J. M. S. and Khaliq, Q. A. (2013). Evaluation of coriander (Coriandrum sativum L.) genotypes for seed yield and yield contributing characters. Bangladesh J. Agric Res. 38(2): 189-202

Nithya, V. (2015). Evaluation of antidiarrheal activity on Coriandrum sativum L. in Wistar albino rats. World J Pharm Res 4(5):638-643
Phurailatpam, A. K, Geetha, K.A., Meena, R. $S$ and Maiti, S (2016). Evaluation of coriander (Coriandrum sativum L.) cultivars for yield and yield contributing characters in Gujarat $J$. Spices and Aromat. Crops. 25 (1): 7-12

Singh, S. K., Kakani, R. K., Meena, R. S., Pancholy, A., Pathak, R., Raturi, A. (2012). Studies on genetic divergence among Indian varieties of spice herb, Coriandrum sativum

Singh, S. K., Singh, S. J., Singh, D and Tripathi, S. M. (2011) Association analysis in elite germplasm lines in coriander (Coriandrum sativum L.). Ann. Hort. 4 (2): 187-192

Thamburaj and Singh, N. (2004). Vegetables and tuber crops and spice, Published by Directorate of information and publication of Agriculture (ICAR), New Delhi: 372-73

\section{How to cite this article:}

Akoijam Ranjita Devi and Sharangi, A.B. 2019. Morphological Character and Seed Yield Potential of Coriander Genotypes under Gangetic Alluvial Region of West Bengal. Int.J.Curr.Microbiol.App.Sci. 8(04): 775-782. doi: https://doi.org/10.20546/ijcmas.2019.804.085 